\title{
Chaophilic or chaotolerant fungi: a new category of extremophiles?
}

\section{Janja Zajc ${ }^{1}$, Sašo Džeroski ${ }^{2,3}$, Dragi Kocev ${ }^{2}$, Aharon Oren ${ }^{4}$, Silva Sonjak $^{1}$, Rok Tkavc ${ }^{1,5}$ and Nina Gunde-Cimerman ${ }^{1,3 *}$}

\author{
${ }^{1}$ Department of Biology, Biotechnical Faculty, University of Ljubljana, Ljubljana, Slovenia \\ 2 Department of Knowledge Technologies, Jožef Stefan Institute, Ljubljana, Slovenia \\ ${ }^{3}$ Centre of Excellence for Integrated Approaches in Chemistry and Biology of Proteins (CIPKeBiP), Ljubljana, Slovenia \\ ${ }^{4}$ Department of Plant and Environmental Sciences, The Institute of Life Sciences, The Hebrew University of Jerusalem, Jerusalem, Israel \\ ${ }^{5}$ Department of Pathology, Uniformed Services University of the Health Sciences, Bethesda, MD, USA
}

\section{Edited by:}

Mark Alexander Lever, ETH Zürich, Switzerland

Reviewed by:

James A. Coker, University of Maryland, University College, USA Changhong Liu, Nanjing University, China

Katja Sterflinger, University of

Natural Resources and Life

Sciences, Austria

\section{*Correspondence}

Nina Gunde-Cimerman, Department of Biology, Biotechnical Faculty, University of Ljubljana, Jamnikarjeva 101, SI-1000 Ljubljana, Slovenia e-mail: nina.gunde-cimerman@ bf.uni-lj.si
It is well known that few halophilic bacteria and archaea as well as certain fungi can grow at the highest concentrations of $\mathrm{NaCl}$. However, data about possible life at extremely high concentrations of various others kosmotropic (stabilizing; like $\mathrm{NaCl}, \mathrm{KCl}$, and $\mathrm{MgSO}_{4}$ ) and chaotropic (destabilizing) salts $\left(\mathrm{NaBr}, \mathrm{MgCl}_{2}\right.$, and $\left.\mathrm{CaCl}_{2}\right)$ are scarce for prokaryotes and almost absent for the eukaryotic domain including fungi. Fungi from diverse (extreme) environments were tested for their ability to grow at the highest concentrations of kosmotropic and chaotropic salts ever recorded to support life. The majority of fungi showed preference for relatively high concentrations of kosmotropes. However, our study revealed the outstanding tolerance of several fungi to high concentrations of $\mathrm{MgCl}_{2}$ (up to $2.1 \mathrm{M}$ ) or $\mathrm{CaCl}_{2}$ (up to $2.0 \mathrm{M}$ ) without compensating kosmotropic salts. Few species, for instance Hortaea werneckii, Eurotium amstelodami, Eurotium chevalieri and Wallemia ichthyophaga, are able to thrive in media with the highest salinities of all salts (except for $\mathrm{CaCl}_{2}$ in the case of $W$. ichthyophaga). The upper concentration of $\mathrm{MgCl}_{2}$ to support fungal life in the absence of kosmotropes $(2.1 \mathrm{M})$ is much higher than previously determined to be the upper limit for microbial growth (1.26 M). No fungal representatives showed exclusive preference for only chaotropic salts (being obligate chaophiles). Nevertheless, our study expands the knowledge of possible active life by a diverse set of fungi in biologically detrimental chaotropic environments.

Keywords: xerophiles, halophiles, kosmotropes, chaotropes, magnesium chloride, calcium chloride, life limit

\section{INTRODUCTION}

Water is essential to life, and life can only exist within a narrow range of water availability in a particular environment, expressed as water activity $\left(a_{\mathrm{w}}\right)$. Water activity is the effective water content expressed as its mole fraction, therefore pure water has $a_{\mathrm{w}}=$ 1 , all the other solutions have $a_{w}<1$. Types and amounts of solutes present in the environment lower $\mathrm{a}_{\mathrm{w}}$ to various values and exert additional effects on the growth of microorganismscausing osmotic pressure and/or have toxic effects. The lowest $\mathrm{a}_{\mathrm{w}}$ known to support life is 0.61 , measured for the xerophilic fungus Xeromyces bisporus grown on sugar-based media (Pitt and Hocking, 2009), and also for some halophilic Archaea and Bacteria (Stevenson et al., 2014). Many fungi are able to thrive at low $a_{w}$, especially the numerous xerophilic filamentous fungi and osmophilic yeasts that grow on drying foods or on foods with high concentrations of sugars (Pitt and Hocking, 1977, 2009).

In the past, fungi were not renowned for growth at high salt concentrations. However, after the first record of fungi as active inhabitants of solar salterns were published (Gunde-Cimerman et al., 2000), the study of halotolerant and halophilic fungi expanded. Since that time numerous fungal species thriving in extremely saline environments around the globe have been described, most of them being halotolerant and extremely halotolerant, and few are obligate halophiles (reviewed in Zajc et al., 2012). The most halophilic fungus known to date is Wallemia ichthyophaga as it requires at least $10 \% \mathrm{NaCl}$ and grows also in solutions saturated with $\mathrm{NaCl}$ (Zalar et al., 2005; Zajc et al., 2014).

Fungi have some common characteristics of osmotolerance, for instance they all employ the compatible solutes strategy: they balance the osmotic pressure of the surroundings by accumulating small organic molecules (compatible solutes), most commonly glycerol, and maintain low intracellular concentrations of salt (such as toxic $\mathrm{Na}^{+}$ions) (reviewed in Gostinčar et al., 2011; Zajc et al., 2012). Sensing and responding to turgor stress (either due to organic osmolytes or due to salt) is under the control of the high osmolarity glycerol (HOG) signaling pathway in all halotolerant and halophilic fungi (Gostinčar et al., 2011). The activation of the HOG pathway results in the production of glycerol, which restores the osmotic balance of the cell (Hohmann, 2009). The cells are equipped with channels allowing for a quick expulsion of glycerol, as well as its active intake when required (Luyten et al., 1995; Ferreira et al., 2005). As the concentration 
of glycerol is carefully regulated, this strategy allows more flexible adaptations to changing salinity. Besides energetically costly synthesis of high concentrations of organic solutes, the cells also use much energy by using different efflux and influx systems to actively eliminate surplus ions, to preserve membrane potential, regulate intracellular $\mathrm{pH}$, and maintain positive turgor of the cell. Hence, the alkali-metal cation transporters are of high importance of the osmoadaptation to extremely saline environments. In fact, the $\mathrm{Na}^{+}$- exporting ATPase (EnaA) is the major determinant of salt tolerance in yeasts (reviewed in Ariño et al., 2010). In addition to the above active mechanisms, fungi also employ some strategies for increasing their stress resistance that may be referred as passive-like clustering cells in compact cell clumps (Palkova and Vachova, 2006; Kralj Kunčič et al., 2010), covering the cells with abundant extracellular polysaccharides or increasing the thickness (Kralj Kunčič et al., 2010), and pigmentation/ melanization (Selbmann et al., 2005; Kogej et al., 2006) of the cell wall.

As most hypersaline environments are rich in $\mathrm{NaCl}$, salt tolerance of fungi and other microorganisms, and mechanisms of adaptations were generally tested by using only $\mathrm{NaCl}$ as the solute. Therefore, the responses to high concentrations of other chaotropic salts remained unknown. However, other salts such as $\mathrm{MgCl}_{2}$ are also abundantly present in nature and can be important or even life-limiting. Salts in the environment not only lower the biologically available water and cause toxicity due to the penetration of certain cations into the cell, but they also modify structural interactions of cellular macromolecules. The Hofmeister series of ions $\left(\mathrm{K}^{+}>\mathrm{Na}^{+}>\mathrm{Mg}^{2+}>\mathrm{Ca}^{2+} ; \mathrm{SO}_{4}^{2-}\right.$ $>\mathrm{HPO}_{4}^{2-}>\mathrm{Cl}^{-}>\mathrm{NO}_{3}^{-}>\mathrm{Br}^{-}>\mathrm{ClO}_{3}^{-}>\mathrm{I}^{-}>\mathrm{ClO}_{4}^{-}$) describes the order of the ability of ions to salt-out or salt-in proteins (Hofmeister, 1888; Kunz et al., 2004). This phenomenon is based on direct interactions between ions and macromolecules and on interactions between ions and water molecules in the first hydration shell of the macromolecule (Zhang and Cremer, 2006). Hofmeister effects of ions on biological structures are either kosmotropic or chaotropic; chaotropes weaken electrostatic interactions and destabilize biological macromolecules, whereas the contrary is true for the kosmotropes (reviewed in Oren, 2013). The difference among the kosmotropic effect of $\mathrm{NaCl}$ on one hand and the chaotropic effect of $\mathrm{MgCl}_{2}$ and $\mathrm{CaCl}_{2}$ on the other hand might explain why high concentrations of $\mathrm{Mg}^{2+}$ and $\mathrm{Ca}^{2+}$ are toxic even to the most halophilic microorganisms (McGenity and Oren, 2012). However, to some extent the chaotropic effects of $\mathrm{Mg}^{2+}$ and $\mathrm{Ca}^{2+}$ can be counteracted by the presence of kosmotropic ions (Williams and Hallsworth, 2009). In fact, few halophilic Archaea can grow at high concentrations of $\mathrm{MgCl}_{2}$, but only in the presence of significant concentrations of $\mathrm{NaCl}$ (Mullakhanbhai and Larsen, 1975; Oren, 1983; Oren et al., 1995). This confirms an early study of interactions among kosmotropic and chaotropic ions on the growth of the halophilic alga Dunaliella salina performed by Baas Becking, who discovered that toxicity of $\mathrm{Ca}^{2+}$ ions was diminished in the presence of sodium ions (Baas Becking, 1934; Oren, 2011).

Two types of hypersaline brines are distinguished with respect to their origin of formation; thalassohaline and athalassohaline (Oren, 2002). Thalassohaline waters, such as marine ponds, salt marshes and solar salterns, originate by evaporation of sea water and are therefore dominated by sodium and chloride ions. During the progression of evaporation, ionic composition changes due to the consecutive precipitation of calcite $\left(\mathrm{CaCO}_{3}\right)$, gypsum $\left(\mathrm{CaSO}_{4} \cdot 2 \mathrm{H}_{2} \mathrm{O}\right)$, halite $(\mathrm{NaCl})$, sylvite $(\mathrm{KCl})$ and final carnalite $\left(\mathrm{KCl} \cdot \mathrm{MgCl}_{2} \cdot 6 \mathrm{H}_{2} \mathrm{O}\right)$ after their solubilities have been surpassed (Oren, 2002, 2013). The major change in the ratio of divalent and monovalent cations occurs when the total salt concentration exceeds $300-350 \mathrm{~g} \mathrm{l}^{-1}$ and most of the sodium (as halite) precipitates. In the remaining brine, so-called bittern, the dominate ion becomes $\mathrm{Mg}^{2+}$ (Oren, 2013).

While NaCl-rich (thalassohaline) environments are well known to support a rich biodiversity, including of fungi, very little is known about the occurrence of fungi and other microorganisms in athalassohaline, $\mathrm{MgCl}_{2}$ - and $\mathrm{CaCl}_{2}$ - dominated environments. Several fungi were isolated from the magnesium and calcium-rich water of the Dead Sea (Oren and Gunde-Cimerman, 2012) [ $\sim 2.0 \mathrm{M}$ and $\sim 0.5 \mathrm{M}$, respectively; total dissolved salts concentration $\sim 350 \mathrm{~g} \mathrm{l}^{-1}$ (Oren, 2013); water activity $\sim 0.683$ (at $35^{\circ} \mathrm{C}$ ) (Hallsworth, personal communication)]. However, most frequently isolation media were supplemented with different $\mathrm{NaCl}$ concentrations (reviewed in Oren and Gunde-Cimerman, 2012) rather than with chaotropic ions such as magnesium and calcium. Recently fungal strains were isolated from the bittern brines of solar salterns (Sonjak et al., 2010), an environment earlier considered sterile due to the high concentrations of magnesium salts (Javor, 1989). These fungal strains showed elevated tolerance to $\mathrm{MgCl}_{2}$, a phenomenon not yet reported for fungi. This raised the issue of the existence of chaophiles among extremophilic fungi. To address the question whether chaotolerant/chaophilic fungi may exist, we have examined a range of them both from bitterns, the Dead Sea and other extreme environments, as well as reference strains from culture collections for their ability to grow at high concentrations of various chaotropic as well as kosmotropic salts.

\section{MATERIAL AND METHODS FUNGAL STRAINS}

The fungal strains studied (listed in Table 1) include culture collection strains known for their halotolerance and/or xerotolerance, and reference strains not known to be derived from hypersaline or dry environments. In addition, we tested strains isolated from bitterns of the Sečovlje (Slovenia) solar salterns. All fungal strains used are maintained in the Ex Culture Collection of the Department of Biology, Biotechnical Faculty, University of Ljubljana (Infrastructural Centre Mycosmo, MRIC UL, Slovenia).

\section{SCREENING OF THE FUNGAL GROWTH IN MEDIA OF VARIOUS SALT CONCENTRATION AND COMPOSITION}

Strains were first inoculated on MEA without additional salts, except for the special strains that are obligately xerophilic (Xeromyces bisporus FRR525/EXF-9116) or halophilic (Wallemia ichtyophaga EXF-1059, -5676, -994, -6068, -8617 and W. muriae EXF-753, $-2361,-8359,-951)$. For the latter two species, MEA was supplemented with $2 \mathrm{M} \mathrm{NaCl}$, whereas for X. bisporus MEA was supplemented with $30 \%(\mathrm{w} / \mathrm{v})$ glucose. After 


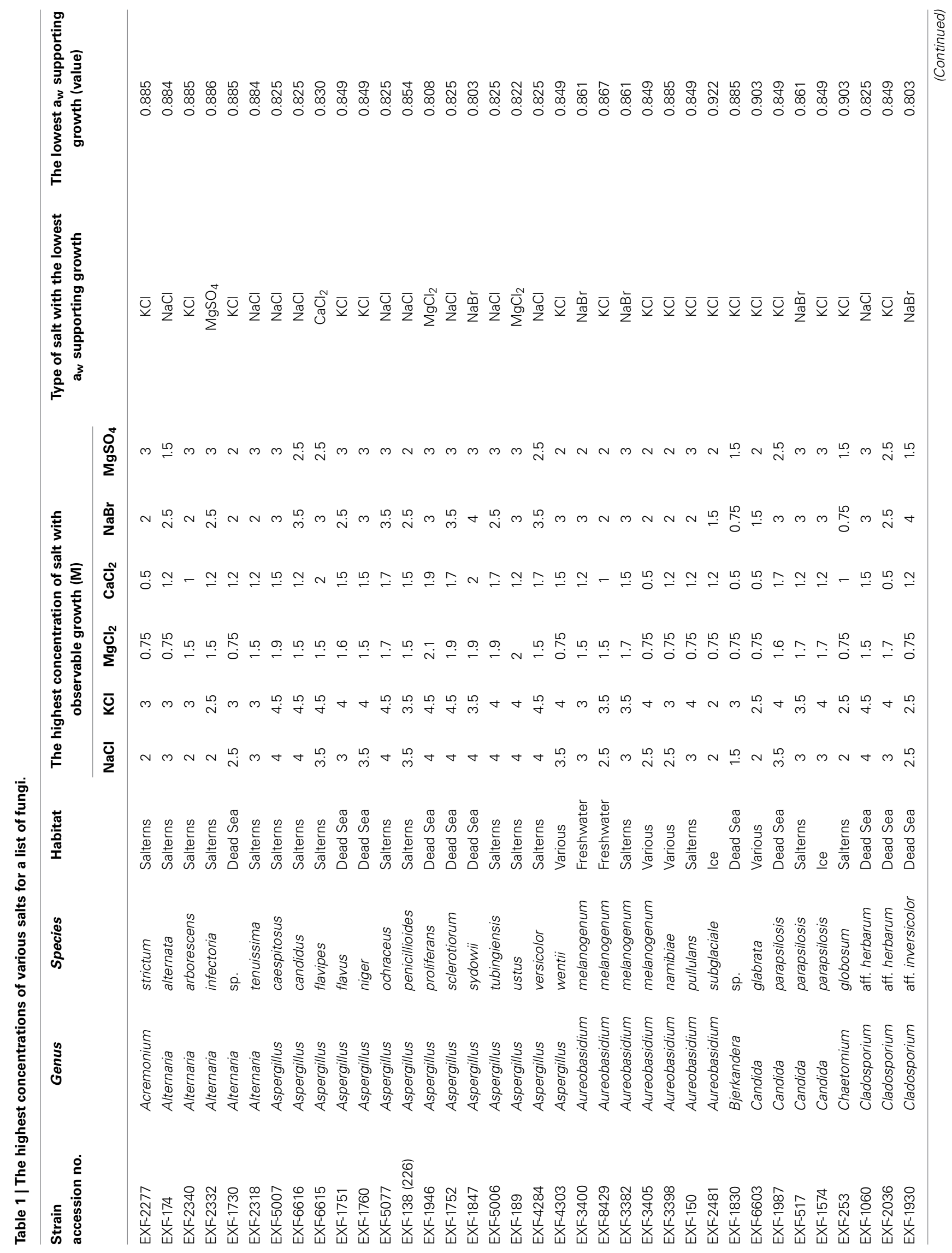




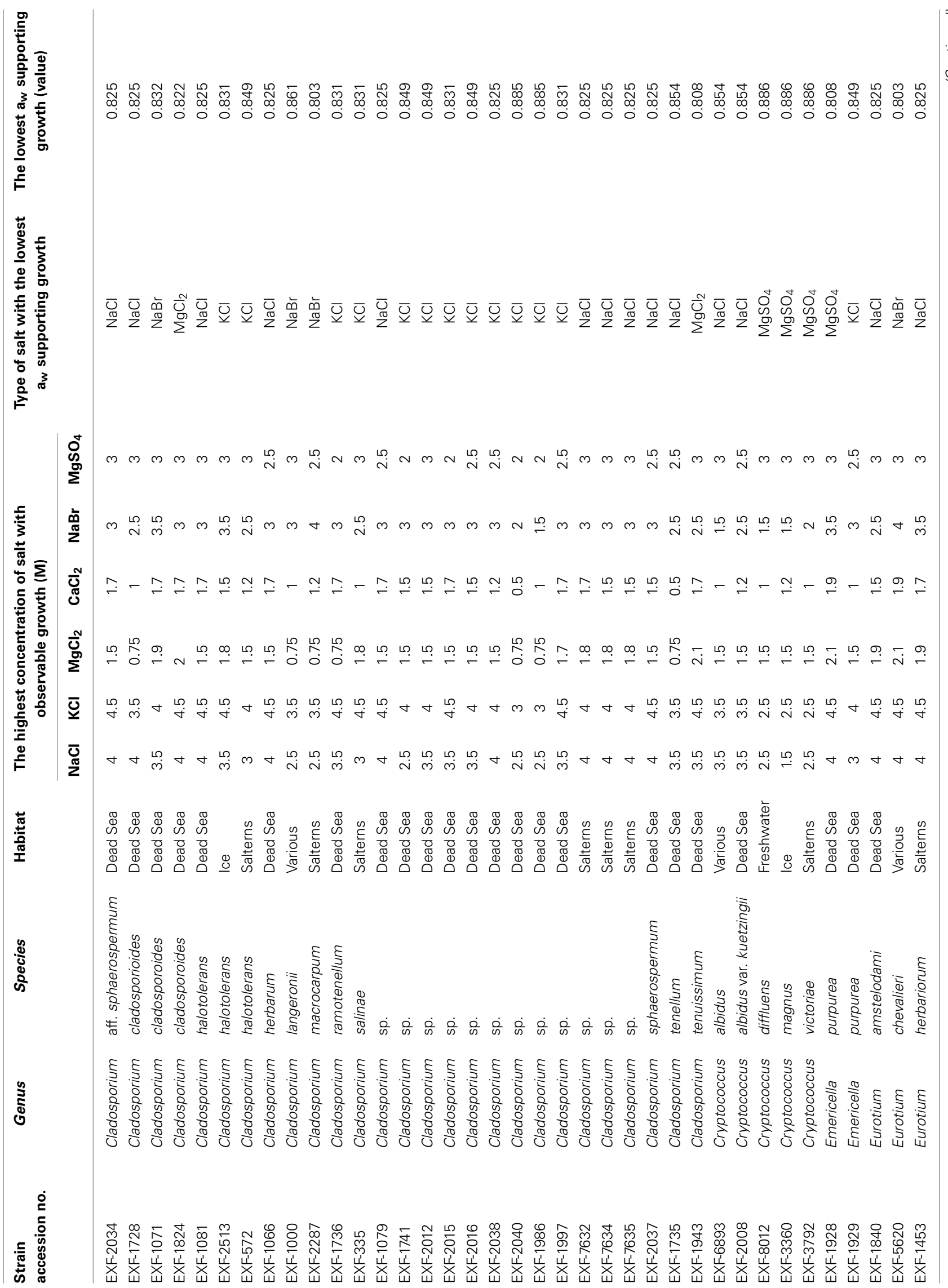




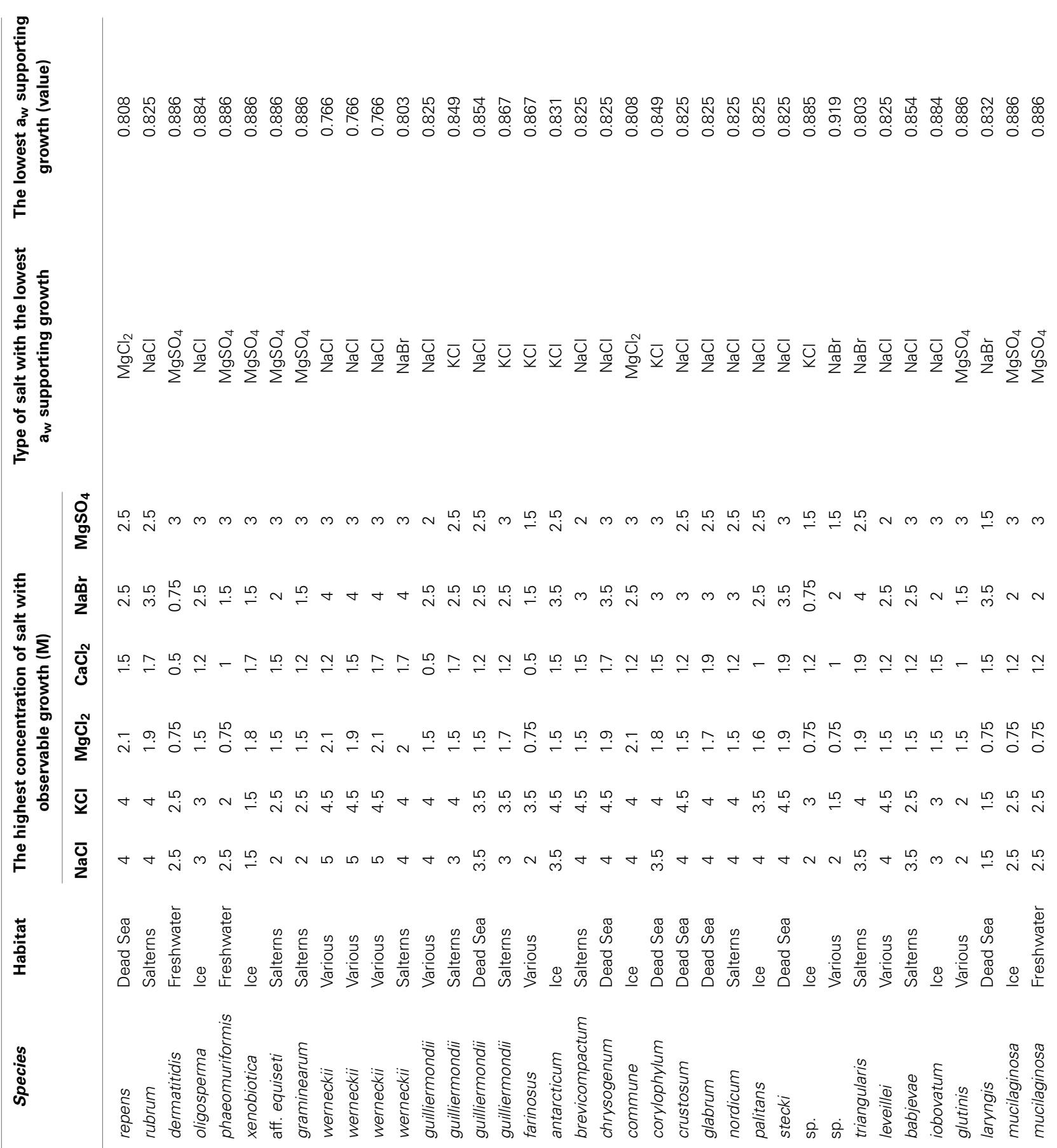

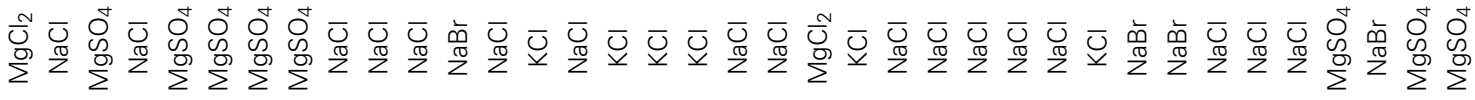

然

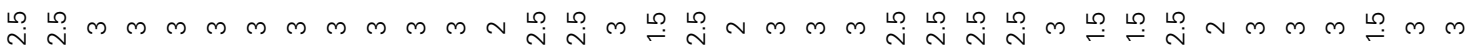

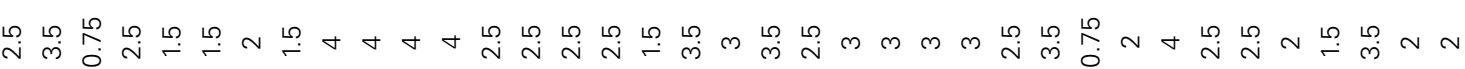

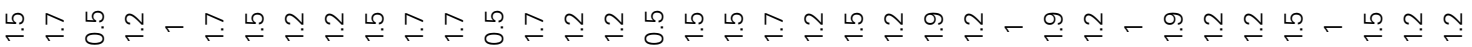

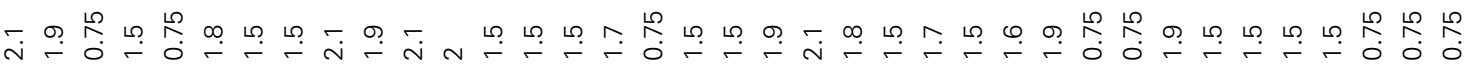

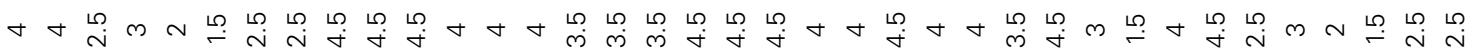

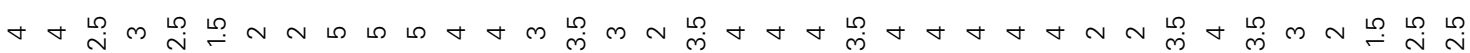

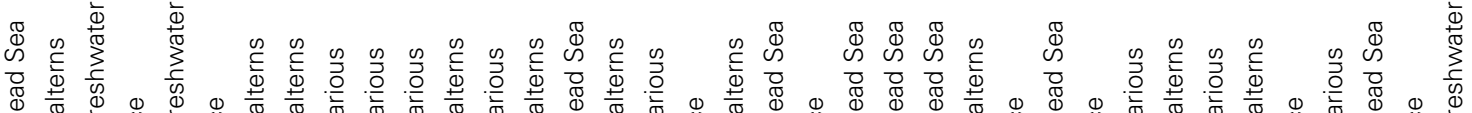

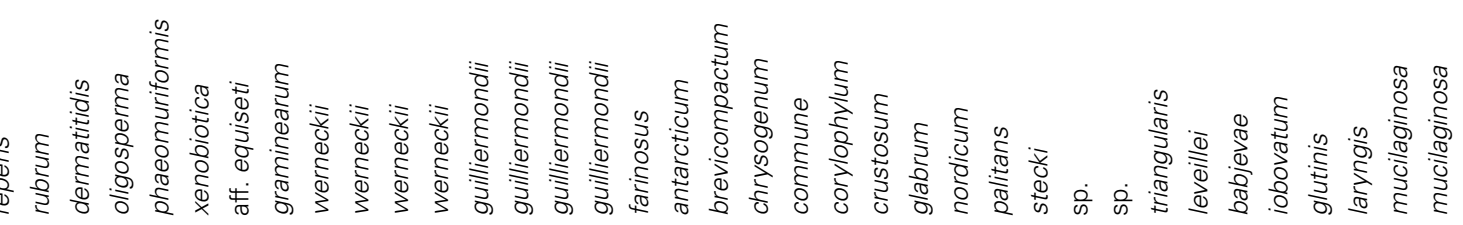

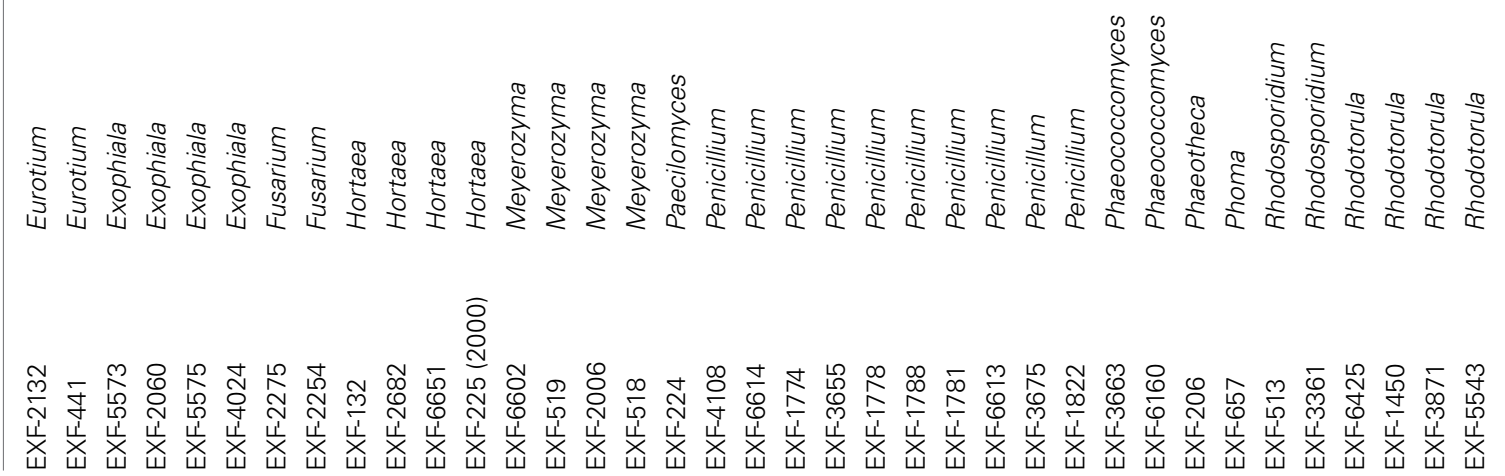




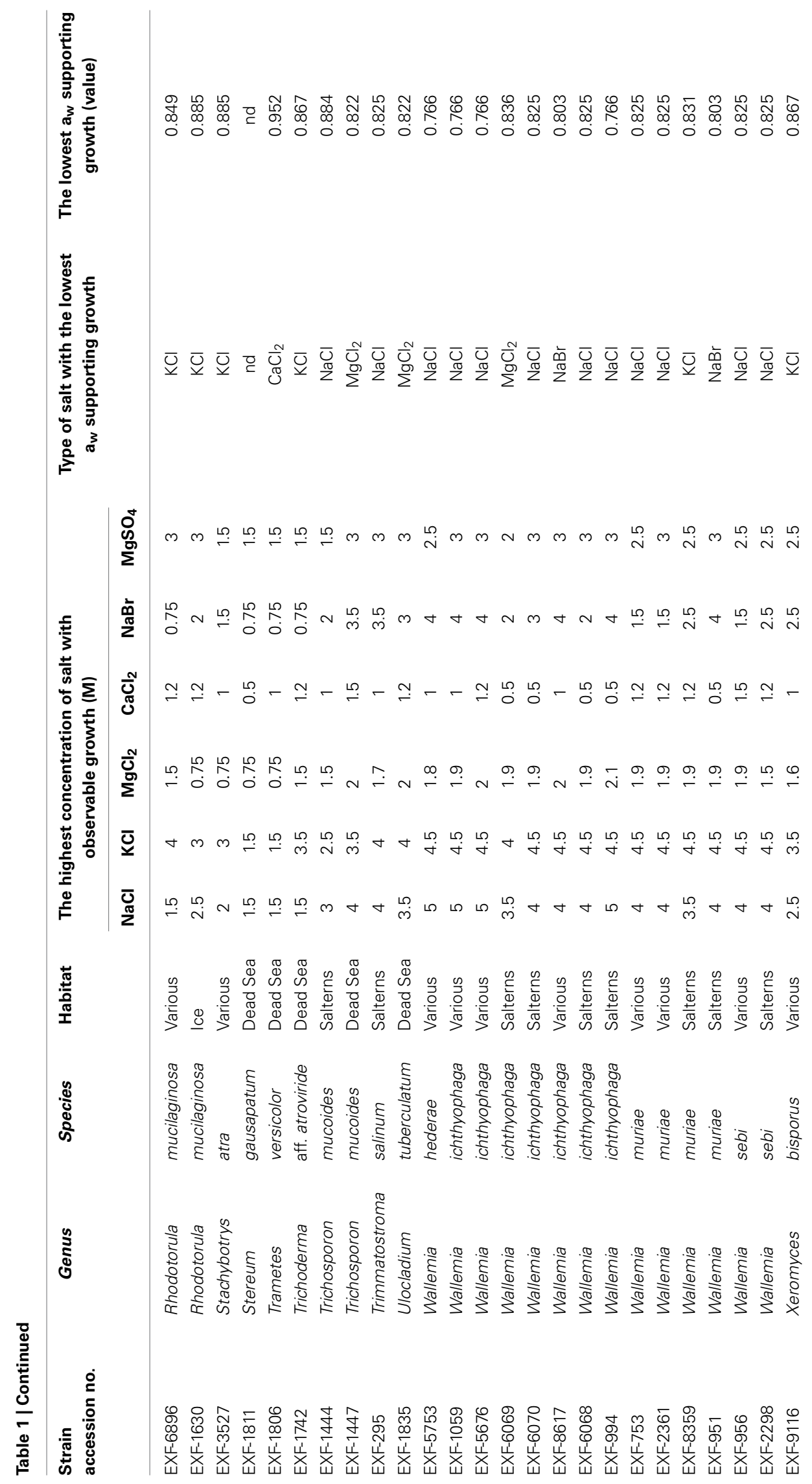


$7-14$ days of incubation at $24^{\circ} \mathrm{C}$ in the dark, spore suspensions were prepared using spore suspension solution $(0.05 \%(\mathrm{w} / \mathrm{v})$ Tween $80,0.05 \%$ agar, $0.9 \% \mathrm{NaCl}$ ). The optical density of the spore suspensions were measured at $600 \mathrm{~nm}$ and adjusted to $\sim 0.8$. Spore suspension $(50 \mu \mathrm{l})$ was added to $2 \mathrm{ml}$ of the liquid Malt Extract (ME) medium ( $\mathrm{pH} 7$ ) supplemented with various salts $\left(\mathrm{NaCl}, \mathrm{KCl}, \mathrm{NaBr}, \mathrm{MgSO}_{4}, \mathrm{MgCl}_{2}, \mathrm{CaCl}_{2}\right.$ ) of indicated concentrations ( $\mathrm{NaCl}: 2.0,2.5,3.0,4.0,5.0 \mathrm{M}$; NaBr: 1.5, 2.0, 2.5, 3.0, 3.5, 4.0 M; KCl: 2.0, 2.5, 3.0, 4.0, 4.5 M; $\mathrm{MgCl}_{2}$ : 1.5, 1.6, 1.7, 1.8, 1.9, 2.0, 2.1 M; $\mathrm{MgSO}_{4}: 2.0,2.5,3.0 \mathrm{M} ; \mathrm{CaCl}_{2}$ : 1.0, 1.2, 1.5, $1.7,1.9,2.0 \mathrm{M}$ ), and incubated in $12 \mathrm{ml}$ glass test tubes (covered with metal caps and thoroughly wrapped with parafilm) at $24^{\circ} \mathrm{C}$. Inoculated media were examined for visible growth (either in a form of a submerged or surface mycelium or culture turbidity due to growth of yeast cells) after 6 weeks. Negative controls (sterile medium) for each salinity and salt type were included in the experiments. Cultures were examined by light microscopy using Olympus BX51 light microscope equipped with an Olympus DP73 digital camera.

\section{DATA ANALYSIS USING MACHINE LEARNING}

The experiments described above resulted in a dataset with a total of 135 samples. Each of the samples refers to a single fungal strain and is described with environmental conditions (considered as independent or descriptive variables), and the fungal species encountered at each sample (considered as the dependent or the target variable). More specifically, we used the following descriptive variables: habitat (with the possible values of salterns, the Dead Sea, food, freshwater, ice, human, or animal), pigmentation (non-melanized or melanized), cell morphology (filamentous, polymorphic, yeast, or clumps), the lowest $a_{w}$ salt with observable growth, the type of salt with the lowest $\mathrm{a}_{\mathrm{w}}$ still supporting growth, and the highest concentrations of various salts still supporting growth $\left(\mathrm{NaCl}, \mathrm{KCl}, \mathrm{MgCl}_{2}, \mathrm{CaCl}_{2} \mathrm{NaBr}\right.$, and $\left.\mathrm{MgSO}_{4}\right)$. The target variable is the fungal species, described with its taxonomic rank. Taken together, the samples included information from 94 different species from 31 different genera.

The generic data analysis task that we addressed was a task of predictive modeling, relating the environmental conditions (descriptive variables) and the fungal species (target variable). We have defined seven different scenarios for analysis. The descriptive variable(s) for each were as follows: (1) the highest concentrations of salts $\left(\mathrm{NaCl}, \mathrm{KCl}, \mathrm{MgCl}_{2}, \mathrm{CaCl}_{2} \mathrm{NaBr}\right.$ and $\left.\mathrm{MgSO}_{4}\right)$, (2) habitat and salt concentrations, (3) pigmentation, morphology and salt concentrations, (4) habitat, pigmentation, morphology and salt concentrations, (5) habitat, lowest $\mathrm{a}_{\mathrm{w}}$ (type of salt), lowest $\mathrm{a}_{\mathrm{w}}$ (value) and salt concentrations, (6) habitat, lowest $\mathrm{a}_{w}$ (type of salt and lowest $\mathrm{a}_{\mathrm{w}}$ value), and (7) all descriptive variables.

To analyze the data, we used the machine learning tool CLUS available for download at http://clus.sourceforge.net. More specifically, we used predictive clustering trees (PCTs) for hierarchical classification as models. PCTs are a generalization of decision trees - a machine learning approach commonly used for classification. PCTs are tree-like structures that have internal nodes and leafs. The internal nodes contain tests on the descriptive variables, while leafs represent the predictions about the target variable. PCTs can solve the general task of structured output prediction, including the specific task of hierarchical classification.

We selected PCTs to model the data because of the specific task at hand. Namely, we used the taxonomic rank of the fungi species to create a hierarchy of classes, where different species can belong to the same genera. This clearly defines the prediction task as a task of hierarchical classification. The predictive clustering trees are able to exploit the information contained in the taxonomic rank of the species during the model construction. Furthermore, the PCTs are easily interpretable predictive models. Detailed information about predictive clustering trees for hierarchical classification has been published before (Vens et al., 2008; Kocev et al., 2013; Levatić et al., 2014).

For each scenario, we have constructed a PCT for hierarchical classification. The PCTs for scenarios 1, 3, 4, and 7 are given in Figure 1. The internal nodes contain tests on individual environmental conditions (e.g., $\mathrm{MgCl}_{2}>1.8$ ) and leaves correspond to a specific combination of environmental conditions. In each leaf, the species encountered under the given conditions are listed.

\section{RESULTS}

\section{SCREENING OF THE FUNGAL GROWTH AT VARIOUS SALTS}

We have selected 135 fungal strains covering 94 different species and 31 genera. Amongst the genera with the highest number of strains were Cladosporium (23), Aspergillus, Wallemia (both 14) and Penicillium (10). The selected strains were previously isolated from different aqueous environments that contain high concentrations of salts (44 strains from salterns, 47 strains from the Dead Sea and also 13 strains from the subglacial ice) and from freshwater (6 strains). Additionally, we have included fungi from various habitats (25 representatives) including food, skin (agents of mycoses), and animals. Among the strains from the Dead Sea almost half (22) belong to the genus Cladosporium. We have tested growth of these strains on salts that act as kosmotropes $\left(\mathrm{NaCl}, \mathrm{KCl}\right.$, and $\left.\mathrm{MgSO}_{4}\right)$ and chaotropes $\left(\mathrm{CaCl}_{2}\right.$, $\mathrm{MgCl}_{2}$, and $\mathrm{NaBr}$ ) that are present in these hypersaline environments. The highest concentrations of salts that allowed growth of individual strains are presented in the Table 1. The microscopic growth characteristics of the selected fungal representatives (cell clumps forming W. ichthyophaga EXF-994; a black yeast Hortaea werneckii EXF-225; and filamentous Eurotium repens EXF-2132 and Cladosporium cladosporoides EXF-1824) are represented in Figure 2.

\section{PREDICTIVE CLUSTERING TREES FOR FUNGAL GROWTH}

The predictive clustering trees obtained with the machine learning analysis are presented in Figure 1. When the highest concentrations of salts at which fungi were able to thrive (scenario 1) were used as the only descriptive variables, the decision tree identified chaotropic salts as the most limiting for fungal growth (Figure 1A). The most limiting turned out to be $\mathrm{MgCl}_{2}$ which was at the top of the decision tree, whereas $\mathrm{CaCl}_{2}$ and $\mathrm{NaBr}$ occupied internal nodes. In addition, pigmentation (melanized and non-melanized) and cell morphology (yeast, filamentous, polymorphic and clumps) (scenario 3, 4, and 7; PCT for scenarios 3 and 4 is given in Figure 1B, while for scenario 7 in Figure 1C) turned out to be key features influencing fungal distribution. 
Finally, when all the descriptive variables were used (including the lowest water activity and the type of salt at the lowest water activity to support growth), pigmentation was again the key variable, whereas morphology divided fungi at internal nodes and finally the lowest water activity and the type of salt in the medium with the lowest $\mathrm{a}_{\mathrm{w}}$ led to the leaves (Figure 1C). Among non-melanized filamentous representatives, the ability to grow at $\mathrm{KCl}>3.0 \mathrm{M}$ and among non-melanized non-filamentous yeasts $\mathrm{NaCl}>2.5 \mathrm{M}$ turned out to be the key variables (Figure 1B). Among melanized filamentous fungi, the genus Cladosporium predominated, whereas for so called "black yeasts" the ability to grow at $\mathrm{NaCl}>3.5 \mathrm{M}$ was the criterion to differentiate $H$. werneckii from Aureobasidium sp., Exophiala sp., Phaeotheca sp. and Phaeococcomyces sp. (Figure 1B). When habitat was added to the other variables, almost no changes occurred in the tree (identical tree for scenarios 3 and 4, shown in Figure 1B; very similar trees for scenarios 1 and 2, shown in Figure 1A and Figure S1A).

\section{DISCUSSION}

Few studies have addressed the issue of the tolerance of microorganisms to chaotropic conditions over the years (reviewed in Oren, 2013). Searching for the chaophilic strains from the hypersaline deep-sea Discovery Basin, an environment with the highest salinity ever found in the marine environments-the brine is almost at saturated levels of $\mathrm{MgCl}_{2}(5.15 \mathrm{M}$ ) (van Der Wielen et al., 2005), did not reveal any prokaryotic representatives
(Hallsworth et al., 2007). Instead, a fungus $X$. bisporus, with the lowest $\mathrm{a}_{\mathrm{w}}$ limit so far reported to support life (Pitt and Hocking, 2009), was the first described species of having the preference to chaotropic conditions/solutes as it was able to grow in highly chaotropic media containing up to $7.6 \mathrm{M}$ glycerol (Williams and Hallsworth, 2009) and was markedly intolerant to $\mathrm{NaCl}$ (Pitt and Hocking, 1977). Importantly, its growth on chaotropic solutes like $\mathrm{MgCl}_{2}$ and $\mathrm{CaCl}_{2}$ was not tested.

Indeed, fungi are promising candidates for chaophiles as they can thrive in the environments, such as crystallizer ponds of solar salterns (Gunde-Cimerman et al., 2000; Butinar et al., 2005a,b), hypersaline water of the Dead Sea (reviewed in Oren and GundeCimerman, 2012) as well as the brine channels of sea ice (GundeCimerman et al., 2003; Sonjak et al., 2006). As these fungi have not previously been examined for their ability to grow in media dominated by chaotropic ions, we have carried out an extensive screening of tolerance to various salts.

Our search for the chaophilic characters of fungi based on their isolation from bittern brines (Sonjak et al., 2010), residual water after the precipitation of $\mathrm{NaCl}$, which is highly enriched with magnesium salts, mostly $\mathrm{MgCl}_{2}$. These brines were long considered sterile as high concentrations of $\mathrm{Mg}^{2+}$ are often toxic for biological systems. However, it was shown recently that bittern brines of the Sečovlje salterns (Slovenia) are not completely free of living microorganisms. They harbor different filamentous fungi, Cladosporium spp., black and other yeasts, albeit their abundance

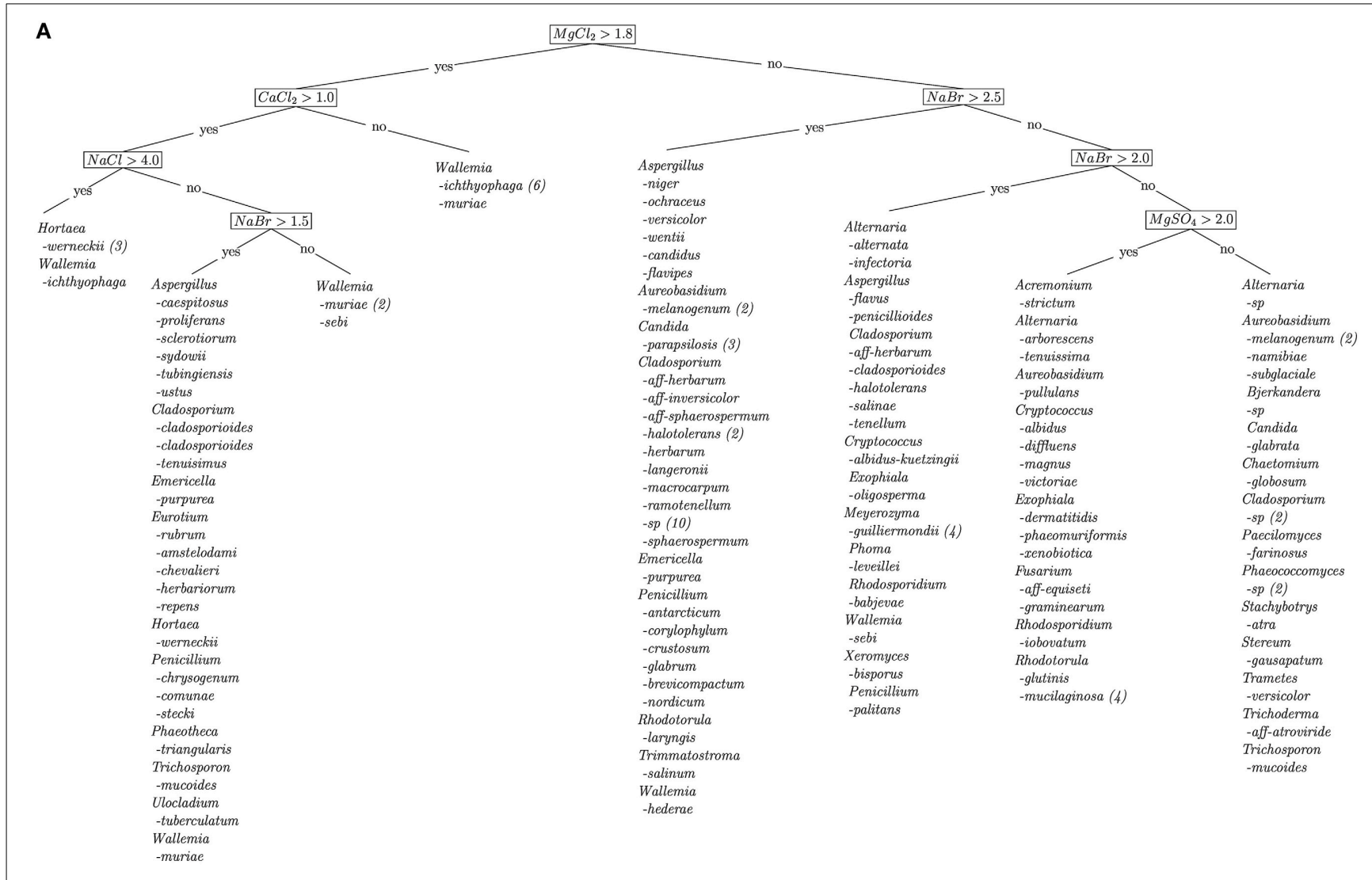

FIGURE 1 | Continued 


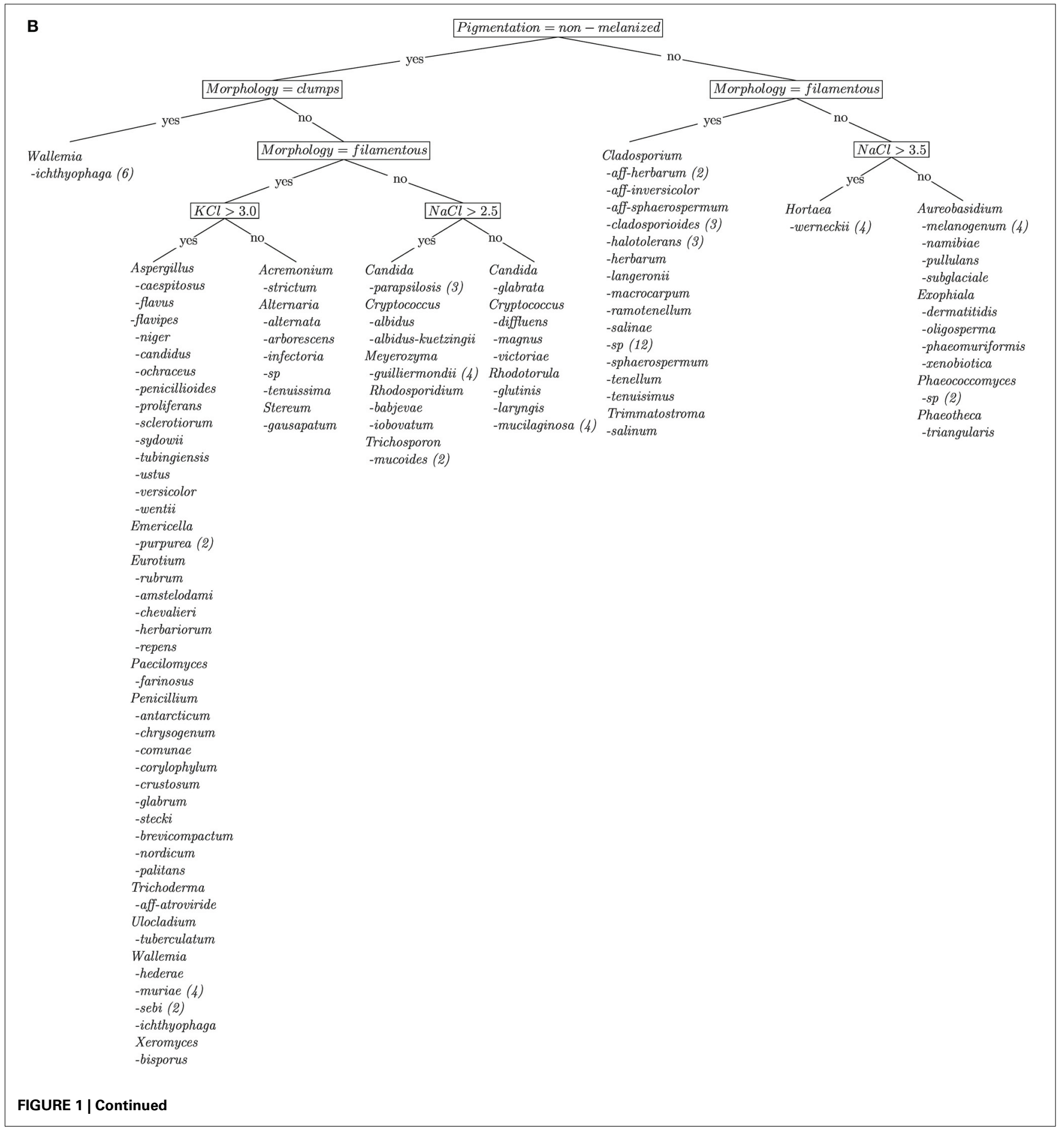

and biodiversity is low when compared to the hypersaline water of the salterns (Sonjak et al., 2010). The lower diversity and abundance might be a consequence of a combination of various factors in situ, such as prolonged exposure to solar radiation and magnesium, its life-limiting effect and nutrient availability.

However, the ionic composition of the bittern brine is not completely unfavorable for microbial growth despite extremely low water activity (0.737); the level of toxic ion $\mathrm{Mg}^{2+}$ is compensated by a relatively higher concentration of $\mathrm{Na}^{+}$. An outstanding discovery here was that these fungi isolated either from brine rich in $\mathrm{MgCl}_{2}$ or $\mathrm{NaCl}$ were able to grow at high concentrations of $\mathrm{MgCl}_{2}(1.5 \mathrm{M}$ ) (Sonjak et al., 2010)higher than previously reported for prokaryotes $\left(1.26 \mathrm{M} \mathrm{MgCl}_{2}\right)$ (Hallsworth et al., 2007). This observation led to the study of the ability of a list of fungi, composed of the isolates from the Dead Sea and the reference strains from our culture collection, to grow in media with low $\mathrm{a}_{\mathrm{w}}$ due to high concentrations of not only kosmotropic salts $(\mathrm{NaCl}, \mathrm{KCl}$, 


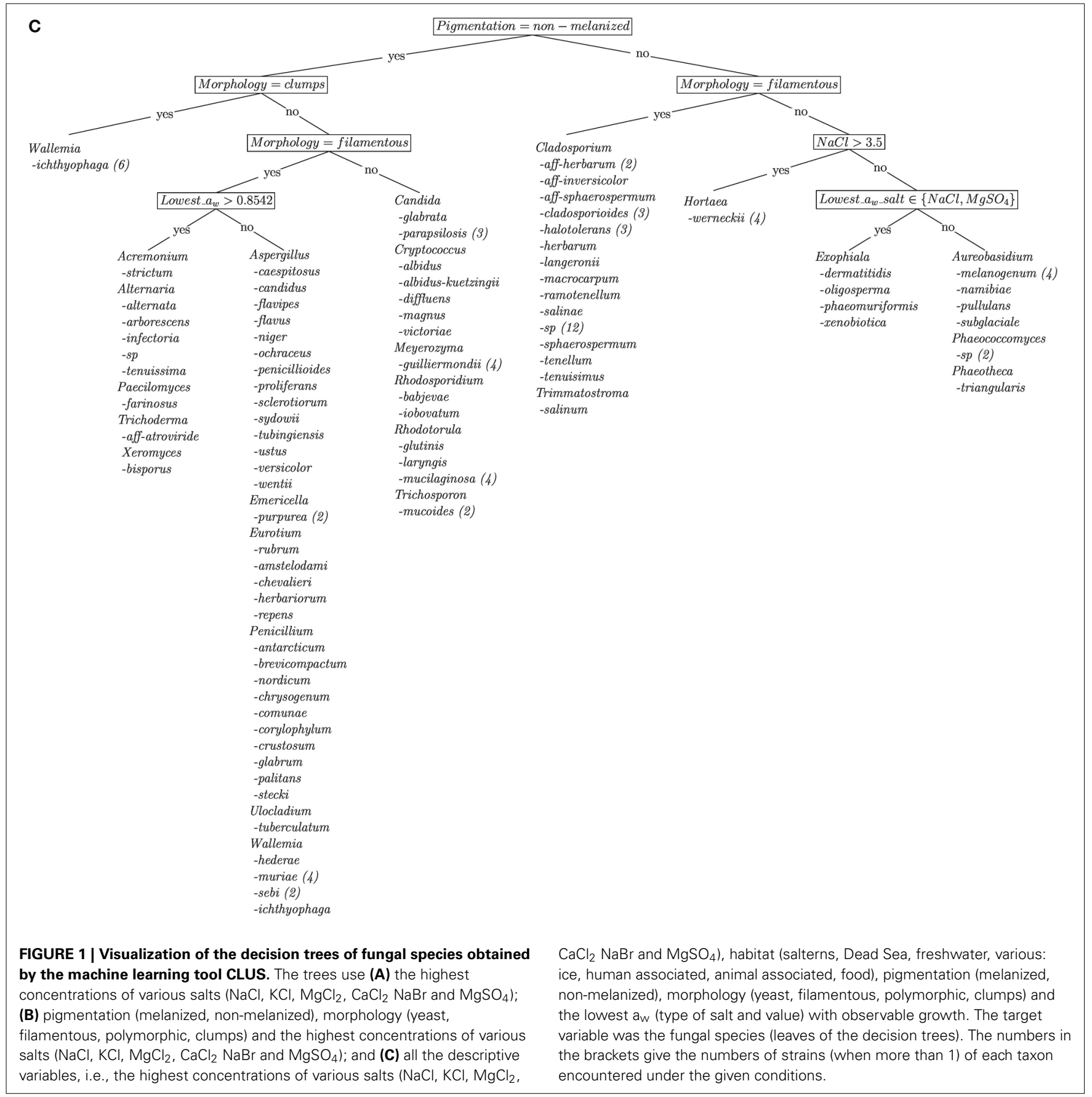

$\mathrm{MgSO}_{4}$ ) but also chaotropic salts such as $\mathrm{NaBr}, \mathrm{MgCl}_{2}$, and $\mathrm{CaCl}_{2}$.

Among the extremophilic fungi included in our study, 104 (almost $80 \%$ of the strains) were able to grow at concentrations of $\mathrm{MgCl}_{2}$ higher than $1.5 \mathrm{M}$, and among these $16(12 \%)$ were able to grow at the highest concentrations of $\mathrm{MgCl}_{2}(\geq 2.0 \mathrm{M})$. Next, 56 (41.5\% of the strains) were capable of growth at concentrations of $\mathrm{CaCl}_{2}$ higher than $1.5 \mathrm{M}$, with two of these able to grow at the highest concentration $(2.0 \mathrm{M})$.

The decision trees (more specifically PCTs) obtained by machine learning analysis in various scenarios (Figure 1) revealed

key types of salts influencing the ability of growth of fungi. The most important salts for the limitation of fungal diversity turned out to be the chaotropic salts $\mathrm{MgCl}_{2}, \mathrm{CaCl}_{2}$, and $\mathrm{NaBr}$, whereas $\mathrm{KCl}$ and $\mathrm{NaCl}$ appeared to be the least limiting and were not present in the nodes of the decision tree. The first decision tree (Figure 1A) revealed that 37 strains, including 11 strains of $H$. werneckii and W. ichthyophaga can cope with $\mathrm{MgCl}_{2}$ concentrations higher than $1.8 \mathrm{M}$. Here, the majority of strains of W. ichthyophaga were unique in their ability to tolerate the highest concentrations of $\mathrm{MgCl}_{2}$, but not $\mathrm{CaCl}_{2}$; whereas almost all strains (except for one instance) of $H$. werneckii could grow at 


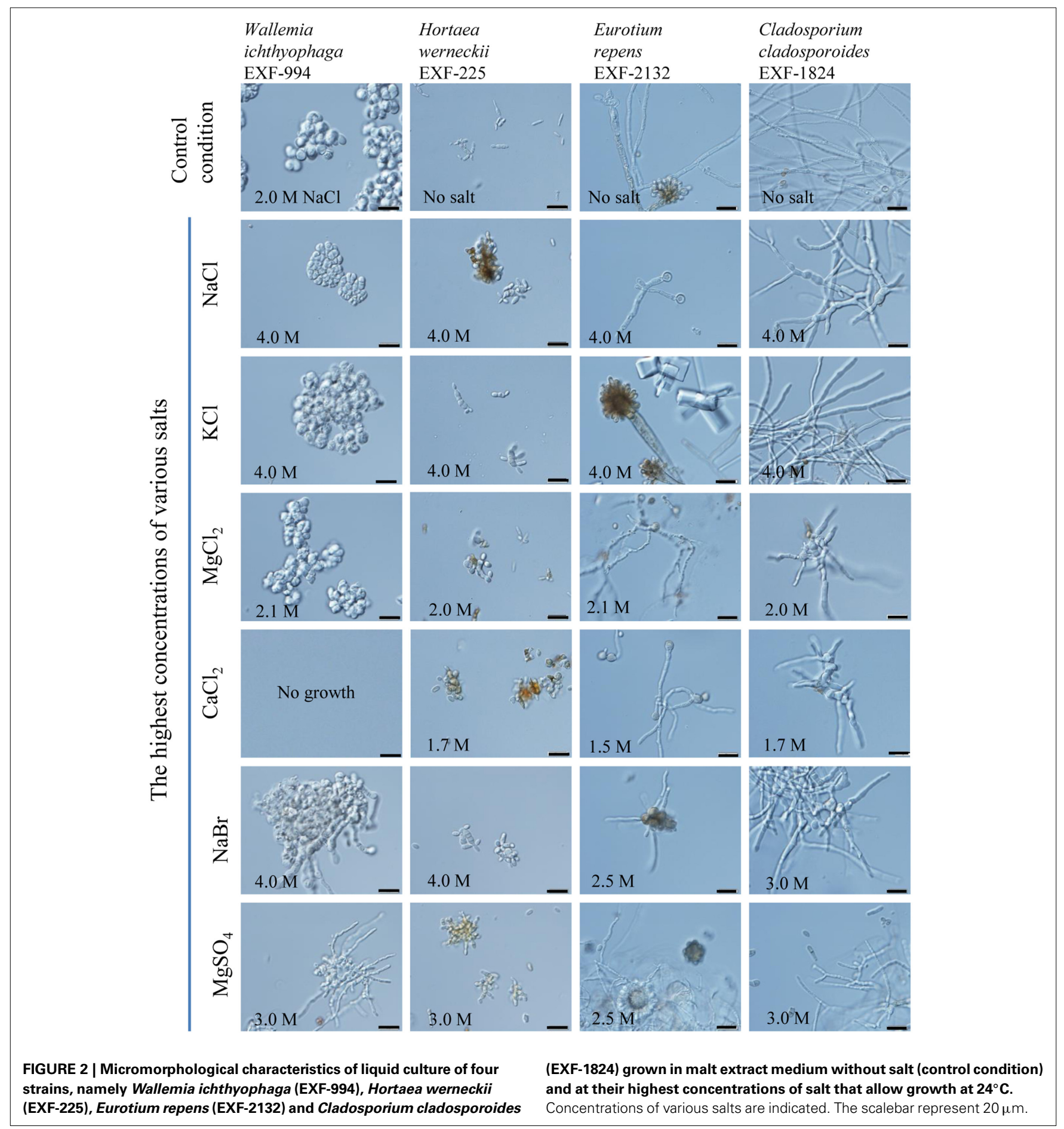

the highest concentrations of all tested salts. Another key variable distinguishing the tested fungal strains is pigmentation, which is at the top of the decision tree using all the variables available. However, melanization is known for its role in UV and other stress responses including in osmoadaptation in halotolerant fungi (Jacobson and Ikeda, 2005; Kogej et al., 2007). Melanin impregnates the outer layer of the cell wall, this decreasing the porosity of the cell wall in order to retain more glycerol, which is most often the main compatible solute (Kogej et al., 2007). Next, cell morphology also appeared high in the decision trees. The ability to form dense clumps of meristematic cells, as observed for W. ichthyophaga and Phaeotheca triangularis, also impacts the ability of fungi to live in stressful conditions (Wollenzien et al., 1995; Palkova, 2004; Palkova and Vachova, 2006).

A simple determination of the type of salt to allow growth of individual strains at the lowest $\mathrm{a}_{\mathrm{w}}$ revealed that the largest number 
of fungi thrived in the media with the lowest $\mathrm{a}_{\mathrm{w}}$ when $\mathrm{NaCl}(52$; $38.8 \%)$ or $\mathrm{KCl}(42 ; 31.3 \%)$ were used as the main solutes. On the contrary, less than $10 \%$ of strains were able to grow in the presence of chaotropic salts, $\mathrm{MgCl}_{2}(10 ; 7.5 \%)$ and $\mathrm{CaCl}_{2}(2 ; 1.5 \%)$, at their lowest $\mathrm{a}_{\mathrm{w}}$. This again emphasizes the life-limiting effects of chaotropic salts. Whether these fungi have the preference for chaotropic salts is inconclusive, as most of them are able to grow also at the highest concentrations of other-kosmotropic-salts. Nevertheless, the fact that they are not only tolerating but growing at such high concentrations of magnesium and/or calcium salts makes these strains the most chaotolerant organisms described so far.

For comparison, the highest concentration of salts to support growth of $X$. bisporus given our results (Table 1) were $2.5 \mathrm{M} \mathrm{NaCl}$, $3.5 \mathrm{M} \mathrm{KCl}, 2.5 \mathrm{M} \mathrm{MgSO}_{4}$ and $2.5 \mathrm{M} \mathrm{NaBr}$, albeit growth was poor. In addition it was also able to grow at $1.5 \mathrm{M} \mathrm{MgCl}_{2}$ and $1 \mathrm{M}$ $\mathrm{CaCl}_{2}$. For the inhibition of growth of $X$. bisporus the $\mathrm{a}_{\mathrm{w}}$ of the medium was clearly not the determining factor-the lowest $a_{w}$ of media tested in our study was 0.867 for medium containing $3.5 \mathrm{M} \mathrm{KCl}$, which is far above its lowest $\mathrm{a}_{\mathrm{w}}$ enabling growth in a glycerol-based medium (Pitt and Hocking, 1977). Here, it seems that high concentrations of salt, regardless of their chao- or kosmotropicity, limit the growth of $X$. bisporus, which clearly prefers sugar-based media as previously reported. Its chaophilic character on organic solutes such as glycerol (Williams and Hallsworth, 2009) must be reconsidered with caution when addressing ionic chaophilic solutes. Poor growth in the presence of salt might be a consequence of the absence of a gene coding for $\mathrm{Na}^{+}$-exporting ATPase (Ena) in the genome of X. bisporus (Leong et al., 2014), whereas this pump is present in multiple copies and/or is differentially expressed in the extremely halotolerant $H$. werneckii (Gorjan and Plemenitaš, 2006; Lenassi et al., 2013) and the halophilic W. ichtyophaga (Zajc et al., 2013).

Hortaea werneckii is a representative of the polyphyletic group of black (melanized) yeasts that have filamentous and yeastlike growth. It is able to grow across the whole range of $\mathrm{NaCl}$ concentrations, from $0 \mathrm{M}$ to saturation, with a broad optimum from $1 \mathrm{M}$ to $2.4 \mathrm{M} \mathrm{NaCl}$ (Butinar et al., 2005b), and it is thus considered to be the most extremely halotolerant fungus so far described (reviewed in Gostinčar et al., 2011). Amongst all of the melanized fungi $H$. werneckii is the most abundant in the hypersaline water of salterns (Gunde-Cimerman et al., 2000). Our screening revealed that $H$. werneckii strains are able to grow at the highest tested concentrations of salts; in media saturated with kosmotropes (5.0 M NaCl, 4.5 M KCl, 3.0 M MgSO 4$)$ and the highest tested concentrations of chaotropes (2.1 $\mathrm{M} \mathrm{MgCl}_{2}, 1.7 \mathrm{M}$ $\mathrm{CaCl}_{2}$, and 4.0 M NaBr) (Table 1 and Figure 2). This exceptional ability might be linked to the redundancy of plasma membrane $\mathrm{Na}^{+}$and $\mathrm{K}^{+}$transporters encoded in its duplicated genome (Lenassi et al., 2013).

The genus Aureobasidium (de Bary) G. Arnaud is a widespread osmotolerant (Kogej et al., 2005) representative of black yeast associated with numerous habitats from hypersaline waters, Arctic glaciers, plant surfaces and household dust (reviewed in Gostinčar et al., 2014). In the genus, recently four new species were introduced A. pullulans, A. melanogenum, A. subglaciale and A. namibiae in Gostinčar et al. (2014). All of them are described as polyextremotolerant (Gostinčar et al., 2010, 2011) capable of surviving also hypersaline conditions (GundeCimerman et al., 2000). The maximum concentrations of $\mathrm{NaCl}$ supporting growth of $A$. pullulans was reported to be $2.9 \mathrm{M} \mathrm{NaCl}$ (Kogej et al., 2005). Our study confirmed the upper limit of $\mathrm{NaCl}$ for Aureobasidium sp. and revealed its ability for growth at high concentrations of $\mathrm{KCl}(4.0 \mathrm{M})$ and $\mathrm{MgSO}_{4}(3.0 \mathrm{M})$, but not extremely high concentration of $\mathrm{MgCl}_{2}$ (lower than $1.5 \mathrm{M}$ ) and $\mathrm{CaCl}_{2}$ (up to $1.2 \mathrm{M}$ ). Aureobasidium spp. can thus be considered kosmophilic. Recent genome analysis uncovered a large repertoire of plasma-membrane transporters in the four Aureobasidium species (Gostinčar et al., 2014). A. melanogenum, which is heavily melanized, is able to grow at the highest concentrations of all salts among the four tested species of the genus Aureobasidium, and the least melanized $A$. subglaciale on the other hand thrives at the lowest. Here, it seems that melanization is required for the highest salt tolerance. The role of melanin in osmoadaptation was shown previously by modifying the permeability of the cell wall in order to retain the compatible solute glycerol (Jacobson and Ikeda, 2005; Kogej et al., 2006).

Representatives of the cosmopolitan genus Cladosporium are frequently found in habitats characterized by low $\mathrm{a}_{\mathrm{w}}$, like foods preserved with sugar or salt (Samson et al., 2002), salt marshes of Egypt, in the rhizosphere of halophytic plants, and the phylloplane of Mediterranean plants (Abdel-Hafez et al., 1978). They are therefore considered xerotolerant with 0.82 being the minimal $\mathrm{a}_{\mathrm{w}}$ for growth of Cladosporium sphaerospermum (Hocking et al., 1994). Cladosporium spp. are among the most abundant melanized fungi throughout the year in the solar salterns in Sečovlje (Gunde-Cimerman et al., 2000; Butinar et al., 2005b) and Cabo Rojo in Puerto Rico (Cantrell et al., 2006). Five species of the genus Cladosporium were isolated from the Dead Sea (reviewed in Oren and Gunde-Cimerman, 2012). The highest concentration of $\mathrm{NaCl}$ for in vitro growth of various representatives of the genus Cladosporium was reported to be $2.9 \mathrm{M}$ to $3.5 \mathrm{M}$ (Zalar et al., 2007). Strains of the genus Cladosporium exhibited variable tolerance to different types of salts, ranging from the lowest concentrations used in the study to the highest (Table 1). The highest growth concentrations of kosmotropic $\mathrm{NaCl}, \mathrm{KCl}$ and $\mathrm{MgSO}_{4}$ among Cladosporium spp. are respectively $2.5-4.0 \mathrm{M}, 2.5-4.5 \mathrm{M}$ and 2.0-3.0 M. Two strains, C. tenuissimum EXF-1943 and C. cladosporoides EXF-1824, were able to grow at 2.0 or $2.1 \mathrm{M} \mathrm{MgCl}_{2}$ and $1.7 \mathrm{M} \mathrm{CaCl}_{2}$ (Figure 2).

Species of the basidiomycetous genus Wallemia Johan-Olsen can be found in a wide variety of environments characterized by low $\mathrm{a}_{w}$ (Samson et al., 2002; Zalar et al., 2005), such as dried, salty and sweet foods, indoor and outdoor air in urban and agricultural environments, hypersaline water of the salterns on different continents and salt crystals (Zalar et al., 2005). Two species of the genus Wallemia, W. muriae and W. ichthyophaga, are obligate xerophiles with the $\mathrm{a}_{\mathrm{w}}$ growth ranges $0.984-0.805$ and $0.959-0.771$, respectively (Zalar et al., 2005), whereas $W$. sebi is xerotolerant with the ability to grow in media without additional solutes $\left(a_{w}\right.$ growth range: 0.997-0.690) (Pitt and Hocking, 1977). However, in media supplemented with $\mathrm{NaCl}$ as the major solute, the lowest $\mathrm{a}_{\mathrm{w}}$ for the growth of $W$. sebi was reported to be 0.80 (Zalar et al., 2005) corresponding to $4.5 \mathrm{M} \mathrm{NaCl}$. W. muriae can grow up to $4.3 \mathrm{M}$ 
$\mathrm{NaCl}$, while $W$. ichthyophaga can thrive only in media with $\mathrm{NaCl}$ above $1.7 \mathrm{M}$, has an optimum at $2.6-3.5 \mathrm{M} \mathrm{NaCl}$ and can grow up to saturating levels of $\mathrm{NaCl}$ (5.2 M) (Zalar et al., 2005; Zajc et al., 2014). Here, we determined that strains of $W$. ichthyophaga grew well at highest concentrations of $\mathrm{NaCl}$ (above $4.0 \mathrm{M}$ ), $\mathrm{NaBr}$ (4 M) and saturated $\mathrm{KCl}$ and $\mathrm{MgSO}_{4}$, but show quite a variability when cultivated at different concentrations of chaotropes like $\mathrm{MgCl}_{2}$ and $\mathrm{CaCl}_{2}$ (Table 1 and Figure 2). A type strain from the hypersaline waters of salterns ( $W$. ichthyophaga EXF-994) grew also at the $2.1 \mathrm{M} \mathrm{MgCl}_{2}$, whereas it was not able to tolerate high concentrations of calcium (not even $1 \mathrm{M} \mathrm{CaCl}_{2}$ ). W. ichthyophaga is indeed the most halophilic fungus ever described. Interestingly, its genome analysis showed that the life in extremely saline environments is possible even with low number of cation-transporter genes, and seems independent of their low transcription and nonresponsiveness to variable salinity. In this case, the role of passive barriers against high salinity conditions seems crucial. The cell wall is unusually thick, the cells are joined into thick multicellular clumps and the cell-wall proteins, hydrophobins, are among the highly expressed genes in saline environments (Zajc et al., 2013).

The filamentous fungi of the order Eurotiales, comprised of teleomorphic genera Eurotium and Emericella, and the anamorphic Aspergillus and Penicillium, are commonly found in different salterns around the World (Cantrell et al., 2006; Butinar et al., 2011) as well as in the Dead Sea (reviewed in Oren and GundeCimerman, 2012). Tolerance for high salt concentrations has been known for many food-borne species (Tresner and Hayes, 1971). The representatives of Aspergillus and Penicillium are most abundant at salinities below $1.7 \mathrm{M} \mathrm{NaCl}$ in the solar salterns (Butinar et al., 2011); however, the in vitro determined salinity growth ranges of the Eurotium spp. are broad, ranging from 0 up to $4.7 \mathrm{M}$ (Butinar et al., 2005c). Given our results the highest concentrations of salts in which species from the order Eurotiales are able to thrive are highly diverse, ranging from the lowest to highest concentrations tested depending on individual strain (see Figure 2 for Eurotium repens EXF-2132). However, all strains were capable to grow in concentrations higher than $3.0 \mathrm{M} \mathrm{NaCl}, 3.5 \mathrm{M} \mathrm{KCl}$, 2.0 $\mathrm{M} \mathrm{MgSO}_{4}, 2.5 \mathrm{M} \mathrm{NaBr}$ and even over $1.5 \mathrm{M} \mathrm{MgCl}_{2}$ and $1.2 \mathrm{M}$ $\mathrm{CaCl}_{2}$ (except in one incident in the case of $\mathrm{MgCl}_{2}$ and $\mathrm{CaCl}_{2}$ ).

Few halophilic Archaea can grow at high concentrations of $\mathrm{MgCl}_{2}$, but only in the presence of significant concentrations of $\mathrm{NaCl}$ (Mullakhanbhai and Larsen, 1975; Oren, 1983; Oren et al., 1995). For instance, Haloferax volcanii is tolerant to high magnesium as growth is still possible at $1.4 \mathrm{M} \mathrm{Mg}^{2+}$ in the presence of $2 \mathrm{M} \mathrm{Na}^{+}$(Mullakhanbhai and Larsen, 1975). Also, Halobaculum gomorrense is moderately tolerant to $\mathrm{Mg}^{2+}$ with optimal growth at $0.6-1.0 \mathrm{M} \mathrm{Mg}^{2+}$ in the presence of $2.1 \mathrm{M}$ $\mathrm{NaCl}$ (Oren et al., 1995). Another archaeon isolated from the Dead Sea, Halobacterium sodomense, has an extremely high magnesium requirement. It grows optimally even at $1.2 \mathrm{M} \mathrm{MgCl}_{2}$ and $2.0 \mathrm{M} \mathrm{NaCl}$ and still grows, albeit poorly, at $1.8 \mathrm{M} \mathrm{MgCl}_{2}$ and $1.7 \mathrm{M} \mathrm{NaCl}$ and at $2.5 \mathrm{M} \mathrm{MgCl}_{2}$ and $0.5 \mathrm{M} \mathrm{NaCl}$ (Oren, 1983). The upper concentration of solely $\mathrm{MgCl}_{2}$ still supporting life was suggested to be $2.3 \mathrm{M}$ and it based on the presence of specific mRNA indicators of active life, (Hallsworth et al., 2007). However, the highest concentration of $\mathrm{MgCl}_{2}$ (without compensating kosmotropes) showing microbial growth (after 18 months of cultivation) of deep-sea Discovery brine samples was 1.26 M (Hallsworth et al., 2007). Given the fact that it was not uncommon for fungi to thrive at concentrations of $\mathrm{MgCl}_{2}$ higher than $1.5 \mathrm{M}$ without compensating $\mathrm{NaCl}$, it is clear that fungi are truly tolerant to magnesium. Some of these were able to grow at $2.1 \mathrm{M} \mathrm{MgCl}_{2}$, a concentration that is close to the chaotropicity limit of possible life (2.3 M) (Hallsworth et al., 2007).

Fungi from diverse environments (salterns, Dead Sea, ice, freshwater and other) can not only tolerate but also thrive at high concentrations of salts, which are either kosmotropic like $\mathrm{NaCl}, \mathrm{KCl}$ and $\mathrm{MgSO}_{4}$ or-to biological systems more toxicchaotropic like $\mathrm{NaBr}, \mathrm{MgCl}_{2}$, and $\mathrm{CaCl}_{2}$. A few representatives of various species, such as $H$. werneckii, E. amstelodami, E. chevalieri and $W$. ichthyophaga were able to thrive in media with the highest tested salinities of all salts (except in $\mathrm{CaCl}_{2}$ in case of W. ichthyophaga). In addition, several fungi (Aureobasidium spp., Exophiala spp.) exert a tendency toward kosmotropes, as they are able to grow at relatively high concentrations of $\mathrm{NaCl}, \mathrm{KCl}$ and $\mathrm{MgSO}_{4}$, but not at high concentrations of chaotropes, like $\mathrm{MgCl}_{2}$ and $\mathrm{CaCl}_{2}$. However, no fungal representatives showed the preference for the highest concentrations of only chaotropic salts but not for the kosmotropic, i.e., being obligately chaophilic. Nevertheless, our study revealed many representatives of the novel group of chaophiles among fungi, which thrive well above the highest previously determined concentration of $\mathrm{MgCl}_{2}$. The ability to grow in the presence of high concentrations of another potent chaotrope- $\mathrm{CaCl}_{2}$ was addressed for the first time. This expands our knowledge of possible life performance under diverse and most extreme environmental parameters.

\section{ACKNOWLEDGMENTS}

The authors acknowledge financial support from the state budget through the Slovenian Research Agency (Infrastructural Centre Mycosmo, MRIC UL, and Young Researcher Grant to Janja Zajc). The study was also partly financed via the operation "Centre of excellence for integrated approaches in chemistry and biology of proteins" number OP13.1.1.2.02.0005, financed by European Regional Development Fund (85\% share of financing) and by the Slovenian Ministry of Higher Education, Science and Technology (15\% share of financing). The authors (Sašo Džeroski and Dragi Kocev) would like to acknowledge the support of the European Commission through the project MAESTRA - Learning from Massive, Incompletely annotated, and Structured Data (Grant number ICT-2013-612944). The authors thank also to Mojca Šere for the highly appreciated technical assistance. The authors declare that they have no conflict of interests.

\section{SUPPLEMENTARY MATERIAL}

The Supplementary Material for this article can be found online at: http://www.frontiersin.org/journal/10.3389/fmicb. 2014.00708/abstract

Figure S1 | Visualization of the decision trees of fungal species obtained by machine learning tool CLUS. The trees use (A) the habitat (salterns, the Dead Sea, food, freshwater, ice, human, or animal) and the highest concentrations of various salts $\left(\mathrm{NaCl}, \mathrm{KCl}, \mathrm{MgCl}_{2}, \mathrm{CaCl}_{2} \mathrm{NaBr}\right.$ and $\mathrm{MgSO}_{4}$ ); (B) the habitat, the lowest $\mathrm{a}_{\mathrm{w}}$ (type of salt), the lowest $\mathrm{a}_{\mathrm{w}}$ (value) 
and the highest concentrations of various salts; (C) the habitat, the lowest $a_{w}$ (type of salt) and the lowest $a_{w}$ (value). The target variable was the fungal species (leaves of the decision trees). The numbers in the brackets give the numbers of strains (when more than 1) of each taxon encountered under the given conditions.

\section{REFERENCES}

Abdel-Hafez, S., Maubasher, A., and Abdel-Fattah, H. (1978). Cellulosedecomposing fungi of salt marshes in Egypt. Folia Microbiol. (Praha). 23, 37-44. doi: $10.1007 / \mathrm{bf02876594}$

Ariño, J., Ramos, J., and Sychrova, H. (2010). Alkali metal cation transport and homeostasis in yeasts. Microbiol. Mol. Biol. Rev. 74, 95-120. doi: 10.1128/Mmbr.00042-09

Baas Becking, L. G. M. (1934). Geobiologie of Inleiding tot de Milieukunde. Den Haag: W.P. Van Stockum \& Zoon N.V.

Butinar, L., Frisvad, J. C., and Gunde-Cimerman, N. (2011). Hypersaline waters - a potential source of foodborne toxigenic aspergilli and penicillia. FEMS Microbiol. Ecol. 77, 186-199. doi: 10.1111/j.1574-6941.2011.01108.x

Butinar, L., Santos, S., Spencer-Martins, I., Oren, A., and Gunde-Cimerman, N. (2005a). Yeast diversity in hypersaline habitats. FEMS Microbiol. Lett. 244, 229-234. doi: 10.1016/j.femsle.2005.01.043

Butinar, L., Sonjak, S., Zalar, P., Plemenitaš, A., and Gunde-Cimerman, N. (2005b). Melanized halophilic fungi are eukaryotic members of microbial communities in hypersaline waters of solar salterns. Botanica Marina 48, 73-79. doi: 10.1515/Bot.2005.007

Butinar, L., Zalar, P., Frisvad, J. C., and Gunde-Cimerman, N. (2005c). The genus Eurotium - members of indigenous fungal community in hypersaline waters of salterns. FEMS Microbiol. Ecol. 51, 155-166. doi : 10.1016/j.femsec.2004. 08.002

Cantrell, S. A., Casillas-Martinez, L., and Molina, M. (2006). Characterization of fungi from hypersaline environments of solar salterns using morphological and molecular techniques. Mycol. Res. 110, 962-970. doi: 10.1016/j.mycres.2006.06.005

Ferreira, C., Van Voorst, F., Martins, A., Neves, L., Oliveira, R., Kielland-Brandt, M. C., et al. (2005). A member of the sugar transporter family, Stllp is the glycerol $/ \mathrm{H}^{+}$symporter in Saccharomyces cerevisiae. Mol. Biol. Cell 16, 2068-2076. doi: 10.1091/mbc.E04-10-0884

Gorjan, A., and Plemenitaš, A. (2006). Identification and characterization of ENA ATPases HwENA1 and HwENA2 from the halophilic black yeast Hortaea werneckii. FEMS Microbiol. Lett. 265, 41-50. doi: 10.1111/j.1574-6968.2006.00473.x

Gostinčar, C., Grube, M., de Hoog, S., Zalar, P., and Gunde-Cimerman, N. (2010). Extremotolerance in fungi: evolution on the edge. FEMS Microbiol. Ecol. 71, 2-11. doi: 10.1111/j.1574-6941.2009.00794.x

Gostinčar, C., Lenassi, M., Gunde-Cimermna, N., and Plemenitaš, A. (2011). Fungal adaptation to extremely high salt concentrations. Adv. Appl. Microbiol. 77, 71-96. doi: 10.1016/B978-0-12-387044-5.00003-0

Gostinčar, C., Ohm, R., Kogej, T., Sonjak, S., Turk, M., Zajc, J., et al. (2014). Genome sequencing of four Aureobasidium pullulans varieties: biotechnological potential, stress tolerance, and description of new species. BMC Genomics 15:549. doi: 10.1186/1471-2164-15-549

Gunde-Cimerman, N., Sonjak, S., Zalar, P., Frisvad, J. C., Diderichsen, B., and Plemenitas, A. (2003). Extremophilic fungi in arctic ice: a relationship between adaptation to low temperature and water activity. Phys. Chem. Earth 28, 1273-1278. doi: 10.1016/j.pce.2003.08.056

Gunde-Cimerman, N., Zalar, P., de Hoog, S., and Plemenitaš, A. (2000). Hypersaline waters in salterns - natural ecological niches for halophilic black yeasts. FEMS Microbiol. Ecol. 32, 235-240. doi: 10.1111/j.15746941.2000.tb00716.x

Hallsworth, J. E., Yakimov, M. M., Golyshin, P. N., Gillion, J. L., D’auria, G., De Lima Alves, F., et al. (2007). Limits of life in $\mathrm{MgCl}_{2}$-containing environments: chaotropicity defines the window. Environ. Microbiol. 9, 801-813. doi: $10.1111 / j .1462-2920.2006 .01212 . x$

Hocking, A. D., Miscamble, B. F., and Pitt, J. I. (1994). Water relations of Alternaria alternata, Cladosporium cladosporioides, Cladosporium sphaerospermum, Curvularia lunata and Curvularia pallescens. Mycol. Res. 98, 91-94. doi: 10.1016/s0953-7562(09)80344-4

Hofmeister, F. (1888). Zur Lehre von der Wirkung der Salze. Zweite Mittheilung. Archiv. Exp. Pathol. Pharmakol. 247-260.
Hohmann, S. (2009). Control of high osmolarity signalling in the yeast Saccharomyces cerevisiae. FEBS Lett. 583, 4025-4029. doi: 10.1016/j.febslet.2009. 10.069

Jacobson, E. S., and Ikeda, R. (2005). Effect of melanization upon porosity of the cryptococcal cell wall. Med. Mycol. 43, 327-333. doi: $10.1080 / 13693780412331271081$

Javor, B. J. (1989). "Hypersaline environments," in Microbiology and Biogeochemistry, ed U. Schiewer (Berlin: Springer-Verlag Berlin and Heidelberg GmbH \& Co. K), 287-287.

Kocev, D., Vens, C., Struyf, J., and Dzeroski, S. (2013). Tree ensembles for predicting structured outputs. Pattern Recogn. 46, 817-833. doi: 10.1016/j.patcog.2012.09.023

Kogej, T., Gorbushina, A. A., and Gunde-Cimerman, N. (2006). Hypersaline conditions induce changes in cell-wall melanization and colony structure in a halophilic and a xerophilic black yeast species of the genus Trimmatostroma. Mycol. Res. 110, 713-724. doi: 10.1016/j.mycres.2006.01.014

Kogej, T., Ramos, J., Plemenitaš, A., and Gunde-Cimerman, N. (2005). The halophilic fungus Hortaea werneckii and the halotolerant fungus Aureobasidium pullulans maintain low intracellular cation concentrations in hypersaline environments. Appl. Environ. Microbiol. 71, 6600-6605. doi: 10.1128/AEM.71.11.6600-6605.2005

Kogej, T., Stein, M., Volkmann, M., Gorbushina, A. A., Galinski, E. A., and GundeCimerman, N. (2007). Osmotic adaptation of the halophilic fungus Hortaea werneckii: role of osmolytes and melanization. Microbiology 153, 4261-4273. doi: 10.1099/mic.0.2007/010751-0

Kralj Kunčič, M., Kogej, T., Drobne, D., and Gunde-Cimerman, N. (2010). Morphological response of the halophilic fungal genus Wallemia to high salinity. Appl. Environ. Microbiol. 76, 329-337. doi: 10.1128/AEM. 02318-09

Kunz, W., Henle, J., and Ninham, B. W. (2004). "Zur Lehre von der Wirkung der Salze" (about the science of the effect of salts): Franz Hofmeister's historical papers. Curr. Opin. Colloid Interface Sci. 9, 19-37. doi: 10.1016/j.cocis.2004.05.005

Lenassi, M., Gostinèar, C., Jackman, S., Turk, M., Sadowski, I., Nislow, C., et al. (2013). Whole genome duplication and enrichment of metal cation transporters revealed by de novo genome sequencing of extremely halotolerant black yeast Hortaea werneckii. PLoS ONE 8:e71328. doi: 10.1371/journal.pone. 0071328

Leong, S.-L. L., Lantz, H., Pettersson, O. V., Frisvad, J. C., Thrane, U., Heipieper, H. J., et al. (2014). Genome and physiology of the ascomycete filamentous fungus Xeromyces bisporus, the most xerophilic organism isolated to date. Environ. Microbiol. doi: 10.1111/1462-2920.12596. [Epub ahead of print].

Levatić, J., Kocev, D., and Džeroski, S. (2014). "The use of the label hierarchy in hierarchical multi-label classification improves performance," in New Frontiers in Mining Complex Patterns, eds A. Appice, M. Ceci, C. Loglisci, G. Manco, E. Masciari and Z. W. Ras (Heidelberg: Springer International Publishing), 162-177. doi: 10.1007/978-3-319-08407-7_11

Luyten, K., Albertyn, J., Skibbe, W. F., Prior, B. A., Ramos, J., Thevelein, J. M., et al. (1995). Fps1, a yeast member of the MIP family of channel proteins, is a facilitator for glycerol uptake and efflux and is inactive under osmotic stress. $E M B O$ J. 14, 1360-1371.

McGenity, T. J., and Oren, A. (2012). "Life in saline environments," in Life at Extremes. Environments, Organisms and Strategies for Survival, ed E. M. Bell (Walling Ford, UK: CABI International), 402-437.

Mullakhanbhai, M. F., and Larsen, H. (1975). Halobacterium volcanii spec. nov., a Dead Sea halobacterium with a moderate salt requirement. Arch. Microbiol. 104, 207-214.

Oren, A. (1983). Halobacterium sodomense sp. nov., a Dead-Sea halobacterium with an extremely high magnesium requirement. Int. J. Syst. Bacteriol. 33, 381-386.

Oren, A. (2002). Diversity of halophilic microorganisms: environments, phylogeny, physiology, and applications. J. Ind. Microbiol. Biotechnol. 28, 56-63. doi: $10.1038 / \mathrm{sj} / \mathrm{jim} / 7000176$

Oren, A. (2011). "The halophilic world of Lourens Baas Becking," in Halophiles and Hypersaline Environments: Current Research and Future Trends, eds A. Ventosa, A. Oren and Y. Ma (Heidelberg;Dordrecht;London;New York, NY: Springer-Verlag), 215-232.

Oren, A. (2013). "Life in magnesium- and calcium-rich hypersaline environments: salt stress by chaotropic ions," in Polyextremophiles, eds J. Seckbach, A. Oren and H. Stan-Lotter (Dordrecht: Springer Netherlands), 215-232. 
Oren, A., and Gunde-Cimerman, N. (2012). "Fungal life in the Dead Sea," in Biology of Marine Fungi, ed C. Raghukumar (Berlin Heidelberg: SpringerVerlag), 115-132.

Oren, A., Gurevich, P., Gemmell, R. T., and Teske, A. (1995). Halobaculum gomorrense gen. nov., sp. nov, a novel extremely halophilic archaeon from the Dead-Sea. Int. J. Syst. Bacteriol. 45, 747-754.

Palkova, Z. (2004). Multicellular microorganisms: laboratory versus nature. EMBO Rep. 5, 470-476. doi: 10.1038/sj.embor.7400145

Palkova, Z., and Vachova, L. (2006). Life within a community: benefit to yeast long-term survival. FEMS Microbiol. Rev. 30, 806-824. doi: 10.1111/j.15746976.2006.00034.x

Pitt, J. I., and Hocking, A. D. (1977). Influence of solute and hydrogen-ion concentration on water relations of some xerophilic fungi. J. Gen. Microbiol. 101, 35-40.

Pitt, J. I., and Hocking, A. D. (2009). Fungi and Food Spoilage. Dordrecht: Springer. Samson, R. A., Hoekstra, E. S., Frisvad, J. C., and Filtenborg, O. (2002). Introduction to Food- and Airborne Fungi. Baarn: Centraalbureau voor Schimmelcultures.

Selbmann, L., de Hoog, G. S., Mazzaglia, A., Friedmann, E. I., and Onofri, S. (2005). Fungi at the edge of life: cryptoendolithic black fungi from Antarctic desert. Stud. Mycol. 51, 1-32.

Sonjak, S., Frisvad, J. C., and Gunde-Cimerman, N. (2006). Penicillium mycobiota in Arctic subglacial ice. Microb. Ecol. 52, 207-216. doi: 10.1007/s00248-0069086-0

Sonjak, S., Gürsu, B., and Gunde-Cimerman, N. (2010). " $\mathrm{MgCl}_{2}$ tolerant fungi from the bitterns," in 8th International Congress on Extremophiles AZORES 2010 (Ponta Delgada), 109.

Stevenson, A., Burkhardt, J., Cockell, C. S., Cray, J. A., Dijksterhuis, J., Fox-Powell, M., et al. (2014). Multiplication of microbes below 0.690 water activity: implications for terrestrial and extraterrestrial life. Environ. Microbiol. doi: 10.1111/ 1462-2920.12598. [Epub ahead of print].

Tresner, H. D., and Hayes, J. A. (1971). Sodium chloride tolerance of terrestrial fungi. Appl. Microbiol. 22, 210-213.

van Der Wielen, P. W., Bolhuis, H., Borin, S., Daffonchio, D., Corselli, C., Giuliano, L., et al. (2005). The enigma of prokaryotic life in deep hypersaline anoxic basins. Science 307, 121-123. doi: 10.1126/science.1103569

Vens, C., Struyf, J., Schietgat, L., Dzeroski, S., and Blockeel, H. (2008). Decision trees for hierarchical multi-label classification. Mach. Learn. 73, 185-214. doi: 10.1007/s10994-008-5077-3

Williams, J. P., and Hallsworth, J. E. (2009). Limits of life in hostile environments: no barriers to biosphere function? Environ. Microbiol. 11, 3292-3308. doi: 10.1111/j.1462-2920.2009.02079.x

Wollenzien, U., de Hoog, G. S., Krumbein, W. E., and Urzi, C. (1995). On the isolation of microcolonial fungi occurring on and in marble and other calcareous rocks. Sci. Total Environ. 167, 287-294. doi: 10.1016/0048-9697(95)04589-S
Zajc, J., Kogej, T., Ramos, J., Galinski, E. A., and Gunde-Cimerman, N. (2014). The osmoadaptation strategy of the most halophilic fungus Wallemia ichthyophaga, growing optimally at salinities above 15\% NaCl. Appl. Environ. Microbiol. 80, 247-256. doi: 10.1128/AEM. 02702-13

Zajc, J., Liu, Y., Dai, W., Yang, Z., Hu, J., Gostinèar, C., et al. (2013). Genome and transcriptome sequencing of the halophilic fungus Wallemia ichthyophaga: haloadaptations present and absent. BMC Genomics 14:617. doi: 10.1186/14712164-14-617

Zajc, J., Zalar, P., Plemenitaš, A., and Gunde-Cimerman, N. (2012). "The Mycobiota of the Salterns," in Biology of Marine Fungi, ed C. Raghukumar (Berlin Heidelberg: Springer-Verlag), 133-158.

Zalar, P., de Hoog, G. S., Schroers, H. J., Crous, P. W., Groenewald, J. Z., and Gunde-Cimerman, N. (2007). Phylogeny and ecology of the ubiquitous saprobe Cladosporium sphaerospermum, with descriptions of seven new species from hypersaline environments. Stud. Mycol. 58, 157-183. doi: 10.3114/sim.2007.58.06

Zalar, P., de Hoog, G. S., Schroers, H. J., Frank, J. M., and GundeCimerman, N. (2005). Taxonomy and phylogeny of the xerophilic genus Wallemia (Wallemiomycetes and Wallemiales, cl. et ord. nov.). Antonie van Leeuwenhoek 87, 311-328. doi: 10.1007/s10482-0046783-x

Zhang, Y., and Cremer, P. S. (2006). Interactions between macromolecules and ions: the Hofmeister series. Curr. Opin. Chem. Biol. 10, 658-663. doi: 10.1016/j.cbpa.2006.09.020

Conflict of Interest Statement: The authors declare that the research was conducted in the absence of any commercial or financial relationships that could be construed as a potential conflict of interest.

Received: 06 October 2014; accepted: 28 November 2014; published online: 23 December 2014.

Citation: Zajc J, Džeroski S, Kocev D, Oren A, Sonjak S, Tkavc $R$ and Gunde-Cimerman N (2014) Chaophilic or chaotolerant fungi: a new category of extremophiles? Front. Microbiol. 5:708. doi: 10.3389/fmicb.2014.00708

This article was submitted to Extreme Microbiology, a section of the journal Frontiers in Microbiology.

Copyright (c) 2014 Zajc, Džeroski, Kocev, Oren, Sonjak, Tkavc and GundeCimerman. This is an open-access article distributed under the terms of the Creative Commons Attribution License (CC BY). The use, distribution or reproduction in other forums is permitted, provided the original author(s) or licensor are credited and that the original publication in this journal is cited, in accordance with accepted academic practice. No use, distribution or reproduction is permitted which does not comply with these terms. 